tion, followed by a move to the Guided Weapons Department, where he took charge of the Division responsible for experimental projects, control physics and missile aerodynamics. He has for several years specialized in problems relating to ballistic missiles.

Mr. P. A. Hufton

Mr. P. A. Hufrow has been appointed senior superintendent of the Supersonics Division of the Aerodynamics Department, Royal Aircraft Establishment. He was educated at the University of Manchester, graduating in 1933 in engineering. After obtaining his M.Sc. for postgraduate research on flow through labyrinth packing, he joined the Royal Aircraft Establishment in 1934. A period on wind-tunnels was followed by some years on aerodynamic research in flight. He built up and led a strong team dealing with the handling and performance aspects of takeoff and landing and low-speed flight. He moved to the Aircraft and Armament Experimental Establishment at Boscombe Down in 1946, as one of the superintendents, and did much to establish revised methods of performance testing and handling assessment for the new types of aeroplane then emerging, his knowledge being used extensively both by the civil and military authorities. Returning to the Royal Aircraft Establishment in 1953, he took charge of the supersonic aerodynamics group at Farnborough, at a time when supersonic flight was rapidly mounting in importance, and this has now been followed by his new appointment as head of an expanded Supersonics Division of the Aerodynamics Department.

\section{Automation and Technical Education}

A DEBATE on automation in the House of Lords on October 23 was opened by Lord Macdonald of Gwaenysgor, who emphasized the importance of research and of technical training, as also did Lord Crook; Lord Hall suggested that overhaul of training systems in Britain is urgently required. Lord Hailsham replied to the debate on behalf of the Government. $\mathrm{He}$ emphasized that clear-sighted planning, in direct consultation with the workers, is essential if automation is to avoid creating hardship ; this is primarily the responsibility of management. He sees no reason why the consequences of the introduction of automatic machinery cannot be forecast far enough ahead for the individual employer to make his plans for recruitment and re-training his labour force, and to discuss well in advance with representatives of the workers how they will be affected. The Minister of Labour intends to discuss with representatives of employers and trade unions the period of notice in the contract of service and its relation to the length of service previously enjoyed, and has powers to assist transfers and training. In regard to education, Lord Hailsham strongly emphasized the impact which will be made upon the whole educational system of Britain, particularly on general education. It is still insufficiently appreciated that this is the real basis. Parents still do not realize the value of a technical secondary education, although there is increasing need for more craftsmen and technicians of all kinds and for new and modified types of training, and-most important of all--for more technologists and managers. Of non-recurrent grants of more than $£ 25$ million allocated by the University Grants Committee since the War, about one-third has gone to general university buildings of interest to all faculties, and 84 per cent of the remainder has gone to laboratories and other build- ings for research and teaching in science and technology, including medicine. In regard to research, Lord Hailsham said that while the money provided under Conditional Aid Funds has come to an end, the continuation of the studies scheduled in the report on automation is receiving close attention, and it should not be assumed the work will come to an end.

Replying to a question in the House of Commons regarding progress in the extension of facilities for technical education since the publication of the White Paper, Sir David Eccles said on October 25 that the 1957-58 and 1958-59 building programmes have been approved and local education authorities know that they can start more than $£ 40$ millions worth of the five-year programme of capital investment. Eight colleges have been provisionally designated colleges of advanced technology and two designations confirmed. The National Council for Technological Awards has published its conditions for awarding the diploma in technology. The number of sandwich courses has risen from 103 to 168 , and substantial increases of salary, recommended by the Burnham Committee for technical college teachers, have been approved. A committee, drawn from the National Advisory Councils on Education for Industry and Commerce, under the chairmanship of Dr. Willis Jackson, has been set up to report on the supply and training of teachers for technical colleges. The Minister has met representatives of local education authorities about regional co-ordination and interauthority payments.

\section{Awards for Postgraduate Study in Britain}

New arrangements for awards for postgraduate study have been announced by the Ministry of Education and the Department of Scientific and Industrial Research, which have recently concluded in consultation with the Committee of Vice-Chancellors and Principals of Universities of the United Kingdom a full review of the present system. From 1957-58, the Department of Scientific and Industrial Research will offer a considerably increased number of competitive postgraduate awards in science and technology. These awards will be of two kinds: (1) Research Studentships, for postgraduate students seeking two or three years of supervised training in research, leading in most cases to a doctorate of philosophy; and (2) Advanced Course Studentships, for postgraduate students wishing to attend courses of advanced instruction in science and technology of not less than six months duration. The awards will be tenable at technical colleges as well as at universities. Their increased number has been so calculated that it will not normally be necessary for the Ministry of Education nor for local education authorities to make awards for postgraduate study in science or technology. Full details of these awards are being issued by the Department of Scientific and Industrial Research. Present arrangements for awards to students in medicine, dentistry, agriculture and veterinary science are not affected, nor are those for aiding graduates to train as teachers. Applications for the Department of Scientific and Industrial Research awards must be made through university or college authorities, and must reach the Department by March 1, 1957. The Ministry of Education is offering about 250 similar postgraduate awards, to be known as 'State studentships', for postgraduate study in arts subjects. 